
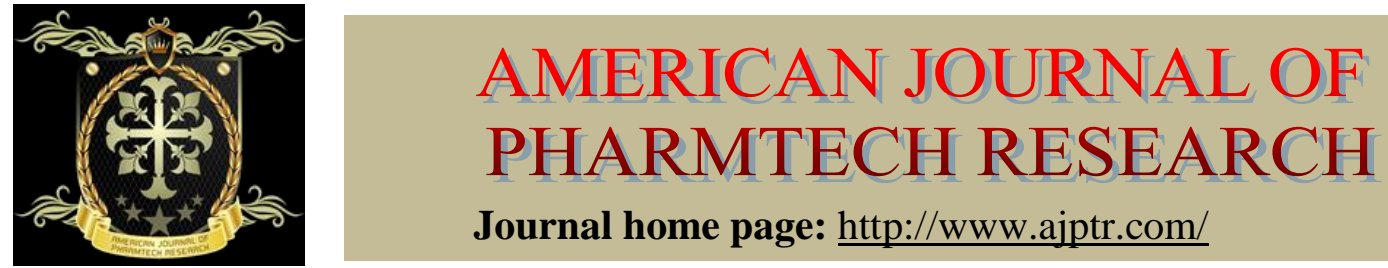

Journal home page: http://www.ajptr.com/

\title{
Evaluation of Wound Healing Activity of Methanolic extract of Annona Squamosa Leaves in Hydrogel delivery system
}

\author{
Himesh Soni*, Jitender Malik, Abhay Pratap Yadav \& Bhavana Yadav
}

R.K. College of Pharmacy, Sathiaon, Azamgarh, Uttar Pradesh - 276608, India

\section{ABSTRACT}

Healing of wounds, whether from accidental injury or surgical intervention, involves the activity of an intricate network of blood cells, tissue types, cytokines, and growth factors. This results in increased cellular activity, which causes an intensified metabolic demand for nutrients and active drug therapy. There are various Phyto-active compounds which required for wound repair may improve healing time and wound outcome. Hydrogel is a cross-linked polymer matrix which has the potential to absorb and hold water in its network structure. Hydrogels act as a moist wound dressing medium and have the ability to absorb and retain the wound exudates along with the foreign bodies, such as bacteria, within its network structure. In addition to this, hydrogels have been found to encourage fibroblast proliferation by minimized the fluid loss from the wound surface and protect the wound from external harm necessary for rapid wound healing. Annona squamosa (Annonaceae). The Indian custard apple known to promotes wound healing as the leaves of the A.squamosa contain tannins and Vitamin $\mathrm{C}$ which promotes wound healing, antiinflammatory and insecticidal activity. For evaluation of wound healing potential of hydrogel formulations various parameters like wound contraction \& tensile strength were assayed. The result represents the reduction of wound area of the different groups over the period of $4^{\text {th }}, 8^{\text {th }}, 12^{\text {th }}$, $16^{\text {th }}$ days. It had been seen that wound healing took place in case of animals treated with $\mathrm{H} 2$ and $\mathrm{H} 3$ formulations. The $\%$ wound contractions were found to be $82.9 \%$ and $80.3 \%$, respectively at $20^{\text {th }}$ day. The period of epithelization was 20 days for both the formulations. The drug content of the $\mathrm{H} 2(0.25 \% \mathrm{w} / \mathrm{w})$ was less than $\mathrm{H} 3(0.50 \% \mathrm{w} / \mathrm{w})$, therefore $\mathrm{H} 2$ formulation was considered as best formulation. The tensile strength was also found to be best in $\mathrm{H} 2$ formulation as compared with standard. 


\section{INTRODUCTION}

Wounds are the physical injuries that result in an opening or breaking of the skin and appropriate method for healing of wounds is essential for the restoration of disrupted anatomical continuity and disturbed functional status of the skin $^{1}$. In other words wound is a break in the epithelial integrity of the skin and may be accompanied by disruption of the structure and function of underlying normal tissue and may also result from a contusion, haematoma, laceration or an abrasion. Healing of wounds starts from the moment of injury and can continue for varying periods of time depending on the extent of wounding and the process can be broadly categorized into three stages; inflammatory phase, proliferate phase, and finally the remodeling phase which ultimately determines the strength and appearance of the healed tissue. The objective in wound management is to heal the wound in the shortest time possible, with minimal pain, discomfort, and scarring to the patient. At the site of wound closure a flexible and fine scar with high tensile strength is desired. Understanding the healing process and nutritional influences on wound outcome is critical to successful management of wound patients.

\section{The Four Phases of Wound Healing}

Tissue injury initiates a response that first clears the wound of devitalized tissue and foreign material, setting the stage for subsequent tissue healing and regeneration. The initial vascular response involves a brief and transient period of vasoconstriction and hemostasis. A 5-10 minute period of intense vasoconstriction is followed by active vasodilation accompanied by an increase in capillary permeability. Platelets aggregated within a fibrin clot secrete a variety of growth factors and cytokines that set the stage for an orderly series of events leading to tissue repair. The second phase of wound healing, the inflammatory phase, presents itself as erythema, swelling, and warmth, and is often associated with pain. The inflammatory response increases vascular permeability, resulting in migration of neutrophils and monocytes into the surrounding tissue. The neutrophils engulf debris and microorganisms, providing the first line of defense against infection. Neutrophil migration ceases after the first few days post-injury if the wound is not contaminated. If this acute inflammatory phase persists, due to wound hypoxia, infection, nutritional deficiencies, medication use, or other factors related to the patient's immune response, it can interfere with the late inflammatory phase. In the late inflammatory phase, monocytes converted in the tissue to macrophages, which digest and kill bacterial pathogens, scavenge tissue debris and destroy remaining neutrophils. Macrophages begin the transition from wound inflammation to wound repair by secreting a variety of chemotactic and growth factors that stimulate cell migration, 
proliferation, and formation of the tissue matrix. The subsequent proliferative phase is dominated by the formation of granulation tissue and epithelialization. Its duration is dependent on the size of the wound. Chemotactic and growth factors released from platelets and macrophages stimulate the migration and activation of wound fibroblasts that produce a variety of substances essential to wound repair, including glycosaminoglycans (mainly hyaluronic acid, chondroitin- 4-sulfate, dermatan sulfate, and heparan sulfate) and collagen. These form an amorphous, gel-like connective tissue matrix necessary for cell migration. New capillary growth must accompany the advancing fibroblasts into the wound to provide metabolic needs. Collagen synthesis and cross-linkage is responsible for vascular integrity and strength of new capillary beds. Improper cross-linkage of collagen fibers has been responsible for nonspecific post-operative bleeding in patients with normal coagulation parameters ${ }^{2}$. Hydrogel (also called Aquagel) is a network of polymer chains that are water-insoluble, and found as a colloidal gel in which water is the dispersion medium. Hydrogels are magnificent absorbent (they can contain over 99\% water) natural or synthetic polymers. Hydrogels also acquire a degree of flexibility very indistinguishable to natural tissue, due to their remarkable water content ${ }^{3}$. Hydrogels are applied to the wound as gels; they required a second cover such as gauze. Besides, if they are applied as films to the wound area, they can be used both as a primary and secondary dressing ${ }^{4}$. Hydrogels suitable for wound dressing as they:

Aid to the rehydration of dead tissues and elevated

the healing of debridement

Suitable for cleansing of dry or necrotic wounds

Act as inert with biological reactants

Penetrable to metabolites

Annona squamosa (A. squamosa) L. (Family: Annonaceae), commonly known as custard apple. Annona squamosa syn. Arabic (gishta); Bengali (ata);German (Rahm Annone, Rahmapfel, Zimtapfel, Süßsack); Hindi (sitaphal, ata, sharifa); Lao (Sino-Tibetan) (khièb); Malay (nona sri kaya,sri kaya, buah nona); Mandarin (fan-li-chi); Portuguese (atta, fructa do conde); Sanskrit (sitaphal); Spanish (candongo, chirimoya, fructo do conde, anón, anona blanca, pinha, saramuya, anona).It is cultivated throughout India, mainly for its edible fruits. It is a semi-evergreen shrub or small tree reaching 6-8 meters $(20-26 \mathrm{ft})$ tall. The plant is traditionally used for the treatment of epilepsy, dysentery, cardiac problems, worm infestation, constipation, hemorrhage, antibacterial infection, dysuria, fever, and ulcer. It also has antifertility, antitumor and abortifacient 
properties $^{5}$.With reference to previous literature leaves shows high DNA content ${ }^{6}$ which influence secondary metabolites content of the plant. Leaves showed presence of vitamin $\mathrm{C}$ which promotes wound healing activity ${ }^{7}$.Flavonoids was also characterized by methanolic extract of leaves of A.squamosa ${ }^{8}$, which also promotes healing process. Moreover the cell viability assay revealed that the methanolic extract of A.squamosa leaves showed significant results. Further phytochemicals screening of the extracts of both the plants revealed presence of Flavonoids on the above extract. The total flavonoids content were determined by aluminum chloride colorimetric method showed that methanolic extracts of A.squamosa leaves were found to be $2.4 \%{ }^{9}$. Consideration of all this crucial literature survey, methanolic extract of leaves of A.squamosa was selected to check the wound healing potential.

\section{MATERIALS AND METHOD}

\section{Materials}

Annona squamosa leaves were collected locally and authenticated. Carbopol 934P and HPMC were purchased from Remkem Lab Pvt Ltd. All other chemicals used were of analytical grade.

\section{Preparation of Hydrogel systems for Pharmacological evaluation}

In separate container, the hydrogel forming polymers were dissolved in small amount of double distilled water in various proportions as shown in Table no.1 and then remaining ingredients i.e. glycerine sodium benzoate were added. Now, active ingredient was added to it and make up the volume up to $100 \mathrm{ml}$. Then, sonicated (Lark probe sonicator) at $6 \varphi$ frequency, $20 \mathrm{sec}$ at $28^{0} \mathrm{C}$. The above formulation was allowed to stand for $24 \mathrm{hrs}$ at room temperature. The $\mathrm{pH}$ of this gel preparation was maintained $6 \pm 0.4$ and stored in well closed container.

\section{Table 1: Composition of Hydrogel formulations}

\begin{tabular}{llll}
\hline S. & & Quantity & \\
No. & Components & $\begin{array}{l}\text { H1 } \\
\mathbf{0 . 2 5 \%}(\mathbf{w} / \mathbf{w})\end{array}$ & $\mathbf{H 2} \mathbf{0 . 5 0 \% ( w / w )}$ \\
\hline 1. & Carbopol 934 & $500 \mathrm{mg}$ & $500 \mathrm{mg}$ \\
2. & HPMC & $500 \mathrm{mg}$ & $500 \mathrm{mg}$ \\
3. & Acaica & $500 \mathrm{mg}$ & $500 \mathrm{mg}$ \\
4. & Glycerine & $2 . \mathrm{ml}$ & $2 . \mathrm{ml}$ \\
5. & Sodium benzoate & $100 \mathrm{mg}$ & $100 \mathrm{mg}$ \\
7. & Methanolic extract of A.squamosa & $40 \mathrm{mg}$ & $80 \mathrm{mg}$ \\
\hline
\end{tabular}

In - vivo Evaluation for Wound Healing Activity

\section{Selection and procurement of animals}

Albino rats were procured and rats of either sex (weighing 150-200 g) were selected, maintained at $24-28^{0} \mathrm{C}$, housed individually with free access to food and water. Rats were fed standard diet and 
kept in well-ventilated animal house with alternate dark-light cycle of $12 \mathrm{hrs}$ throughout the studies (CPCSEA-1323/10-CPCSEA).

To perform the experiment, the mice were divided into seven groups consisting of six animals each.

Group I - CONTROL

Group II - TEST (H1)

Group III - TEST (H2)

Group IV - Standard [Standard Povidone-Iodine (5\% w/w) Ointment]

\section{Excision wound model:}

For the excision wound study, each group containing six animals were selected circular wound of about $2.5 \mathrm{~cm}$ diameter were made depilated dorsal thoracic region of rats were deplicated under light ether anaesthesia in semi-aseptic condition and observed throughout the study. Individually rats were kept in housed. The different groups were divided and treated with hydrogels systems on the wound once daily for 14 days starting from the day of wounding. The observations of percentage wound closures shall be made on $4^{\text {th }}, 8^{\text {th }}, 12^{\text {th }}$ and $16^{\text {th }}$ post wounding days and also epithelization, size and shape of scar noted. All the samples were applied once daily for 16 days, starting from the day of wounding and evaluated for the following parameter ${ }^{10}$.

\section{Wound contraction And Epithelization time:-}

Wound contraction was measured plannimetically using a transparent paper at four days interval. It was observed that after simple ointment treatment, \% wound contraction reached to maximum in 22 days, but in standard group 18 days were found to be required for $100 \%$ contraction or complete wound healing. Mean of epithelization time of extract was found to be lesser (18day) compared to control groups (22 days).

The percentage wound contraction was determined using the following formula

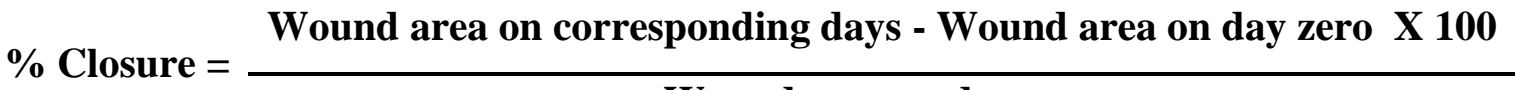 \\ Wound area on day zero}

\section{Incision Wound Model:-}

Under light ether anesthesia, two paravertebral incisions of $6 \mathrm{~cm}$ were made on either side of the vertebral column through the entire thickness of the skin with the help of sharp blade. The incisions were sutured using Ethicon 4-0 silk thread with the help of straight round bodied needle. Sutures shall be removed on $8^{\text {th }}$ post wounding day and the tensile strength shall be determined on $10^{\text {th }}$ post wounding day by using tensiometer. 
Measurement of tensile strength:

Tensile strength is the resistance to breaking under tension. For the newly repaired tissue including scar was excised to measure the tensile strength using Tensiometer ${ }^{10}$.

\section{Evaluation for Wound healing activity}

Excision Wound Model

Table 2: Mean Percentage closure of Excision wound area by different formulations

\begin{tabular}{|c|c|c|c|c|c|c|}
\hline \multirow[t]{2}{*}{ Groups } & \multicolumn{5}{|c|}{ Mean Percentage closure of Excision wound area } & \multirow{2}{*}{$\begin{array}{l}\text { Period of } \\
\text { epithelization }\end{array}$} \\
\hline & Initial & $4^{\text {th }}$ day & $8^{\text {th }}$ day & $12^{\text {th }}$ day & $16^{\text {th }}$ day & \\
\hline Control & 500 & $\begin{array}{l}395.45 \pm 1.52 \\
(20.91 \%)\end{array}$ & $\begin{array}{l}318.14 \pm 0.63 \\
(36.42 \%)\end{array}$ & $\begin{array}{l}176.10 \pm 0.69 \\
(64.78 \%)\end{array}$ & $\begin{array}{l}124.30 \pm 0.60 \\
(75.14 \%)\end{array}$ & 23 day \\
\hline $\begin{array}{l}\mathrm{H} 1(0.25 \% \mathrm{MeoH} \\
\text { w/w) Extract of } \\
\text { A.squamosa }\end{array}$ & $415.64 \pm 0.58$ & $\begin{array}{l}290.94 \pm 0.53 \\
(30.1 \%)\end{array}$ & $\begin{array}{l}190.36 \pm 0.21 \\
(54.2 \%)\end{array}$ & $\begin{array}{l}124.06 \pm 0.12 \\
(70.15 \%)\end{array}$ & $\begin{array}{l}71.07 \pm 0.08 \\
(82.9 \%)\end{array}$ & 20 day \\
\hline $\begin{array}{l}\mathrm{H} 2(0.50 \% \mathrm{MeoH} \\
\text { w/w }) \text { Extract of } \\
\text { A. squamosa }\end{array}$ & $\begin{array}{l}475.65 \pm \\
0.72\end{array}$ & $\begin{array}{l}424.76 \pm 0.37 \\
(10.7 \%)\end{array}$ & $\begin{array}{l}378.16 \\
\pm 0.72 \\
(21.2 \%) \\
\end{array}$ & $\begin{array}{l}191.21 \pm 0.16 \\
(59.8 \%)\end{array}$ & $\begin{array}{l}93.71 \pm 0.08 \\
(80.3 \%)\end{array}$ & 21 days \\
\hline Standard & 210.2 & $\begin{array}{l}126.12 \pm 0.23 \\
(40 \%)\end{array}$ & $\begin{array}{l}58.015 \pm 0.11 \\
(72.4 \%)\end{array}$ & $\begin{array}{l}0.378 \pm .024 \\
(99.82)\end{array}$ & - & 13 days $*$ \\
\hline
\end{tabular}

Values are expressed as Mean $\pm S E M, n=6$ in each group, $P<0.001$ significance Vs control Formulation H1

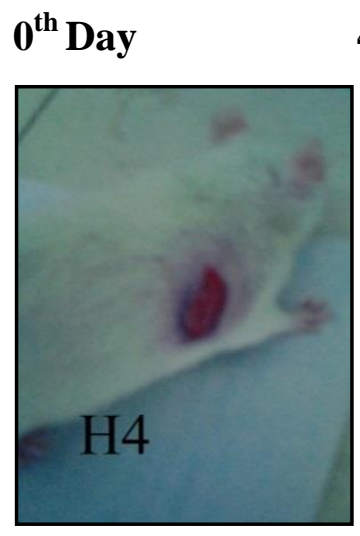

$4^{\text {th }}$ Day

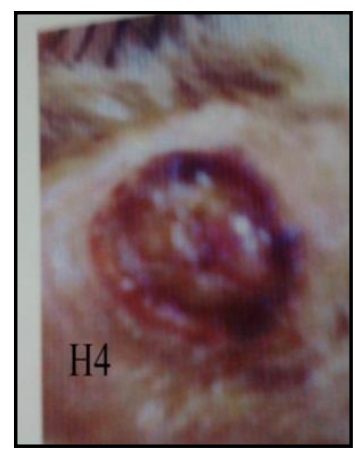

$8^{\text {th }}$ Day

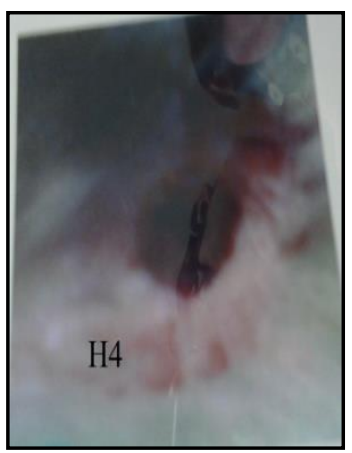

$12^{\text {th }}$ Day

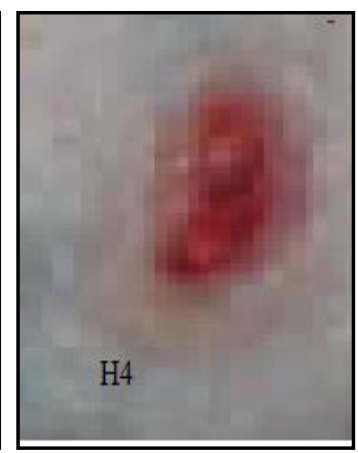

\section{Formulation $\mathbf{H 2}$}

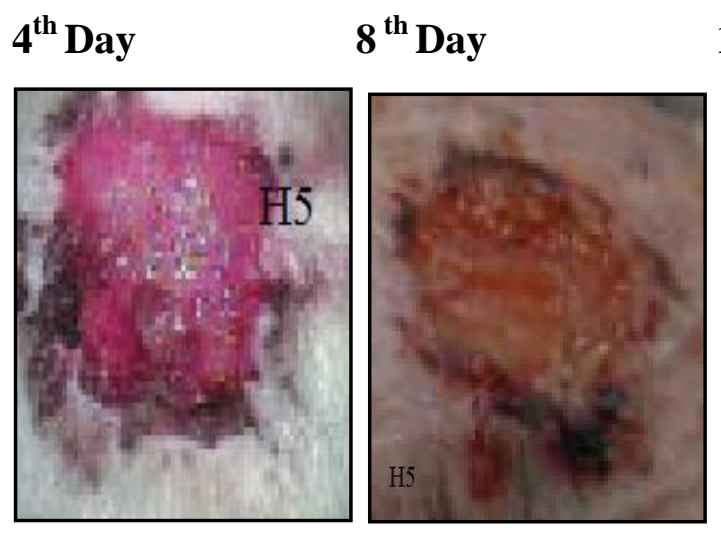

$12^{\text {th }}$ Day

$16^{\text {th }}$ Day
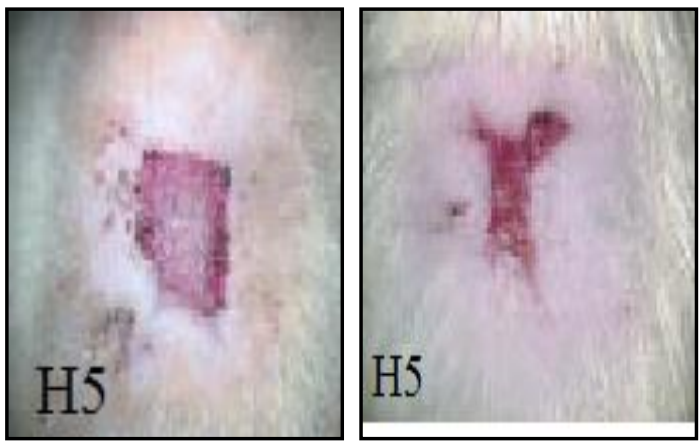
Standard (Povidone iodine ointment)

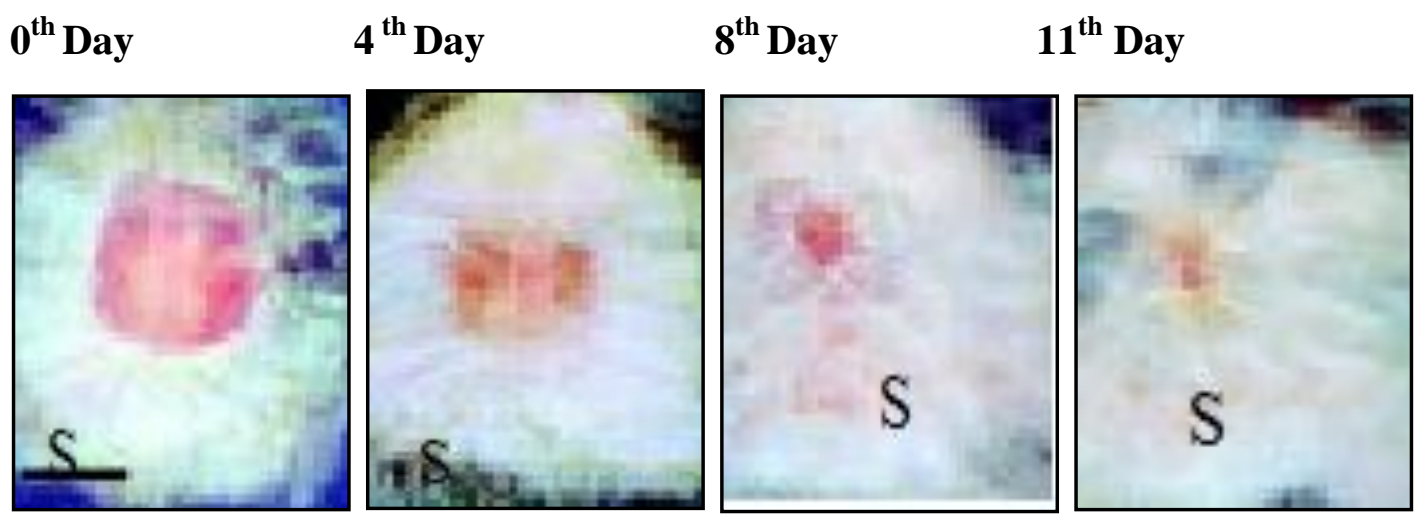

Figure 1: Excision Wound Model

Table 3: Mean Tensile strength of resutured Incision wound on $10^{\text {th }}$ Post Wounding Day

\begin{tabular}{lll}
\hline S. No. & Groups & Breaking strength $(\mathbf{g m})$ \\
\hline 1. & Control & $244.86 \pm 1.47$ \\
2. & H1 & $362 \pm 1.02$ \\
3. & H2 & $336.6 \pm 0.49$ \\
4. & Standard & $419.2 \pm 3.8$ \\
\hline
\end{tabular}

Value are expressed as the Mean $\pm S E M, n=6$ in each group $P<0.001$ significance Vs control RESULTS AND DISCUSSION

The least rate of wound healing was seen in control group. Treatment with standard group heals the wound in a faster rate than other group. The measurement of the progress of the wound healing induced by the standard, hydrogel $(\mathrm{H} 1 \& \mathrm{H} 2)$ and control in the excision wound model were shown in Table 2 \& Fig 1 . The $\%$ wound contractions were found to be $82.9 \%$ and $80.3 \%$, respectively at $20^{\text {th }}$ day. The period of epithelization was 20 days for both the formulations. The drug content of the $\mathrm{H} 2(0.25 \%$ w/w) was less than $\mathrm{H} 3(0.50 \% \mathrm{w} / \mathrm{w})$, therefore $\mathrm{H} 2$ formulation was considered as best formulation. The tensile strength was also found to be best in $\mathrm{H} 2$ formulation as compared with standard. The earlier wound contraction rate of the methanolic leaves extract of $A$. squamosa hydrogel may be due to flavonoid content in methanolic leaves extract. Flavonoids show wound healing properties due to their antibacterial and antioxidant properties. Flavones, flavonoids and flavonol are phenolic structure with single carbonyl group. They are synthesized by plants in response to microbial infection and are often found effective in-vitro as antimicrobial substance against a wide array of microorganisms. Flavonoids are known to promote the wound-healing process mainly due to their antimicrobial potential, which appear to be liable for wound contraction and increased rate of epithelialization. Flavonoids are recognized to reduce lipid peroxidation not only by preventing or slowing the onset of cell necrosis but also by improving 
vascularity ${ }^{11}$.In addition to this, hydrogels have been found to promote fibroblast proliferation by reducing the fluid loss from the wound surface and protect the wound from external noxae necessary for rapid wound healing. Hydrogels of natural origin are known to have several advantages over synthetic. There are so many synthetic drugs available for the treatment of wounds but herbal drugs is preferred due to economic and fewer side effects. Carbopol based hydrogels were selected as delivery system for wound treatment. Among the formulations to be useful on damaged skin, hydrogels have shown the superiority as they can provide a moist environment for the wound and at the same time deliver the incorporated drug to the wound.

\section{CONCLUSION}

On the basis of the results obtained in the present investigation, it is concluded that the various formulations containing methanolic leaves extract of A. squamosa have significant wound healing activity in different extent. The above findings justify the wound healing properties of A.squamosa.

\section{REFERENCE}

1. Meenakshi S, Raghavan G, Nath V, Ajay Kumar SR, Shanta M. Antimicrobial, wound healing and antioxidant activity of Plagiochasma appendiculatum Lehm. et Lind. J Ethnopharmacol. 2006; 107: 67-72.

2. Himesh Soni \& Akhlesh Kumar Singhai. A recent updates of Botanicals for wound healing activity.IRJP.

3. Lin CC and Metters AT. Hydrogels in controlled release formulations: Network design and mathematical modeling. Adv Drug Deliv Rev, 2006, 58:1379-1408.

4. Boateng JS, Matthews KH, Stevens HNE and Eccleston GM. Wound healing dressings and drug delivery systems: A review. Journal of Pharmaceutical Sciences, 2008, 97:28922923.

5. Soni Himesh, Singhai AK And Sharma Sarvesh .Quantification Of Ascorbic Acid In Leaves Of Annona Squamos A . Int J Pharm Pharm Sci, Vol 4, Issue 3, 144-147.

6. Soni Himesh, Singhai AK And Sharma Sarvesh.Quantitative estimation of DNA isolated from various parts of Annona squamosa. IRJP,2(12),2011,169-171.

7. Soni Himesh, Singhai AK And Sharma Sarvesh .Quantification Of Ascorbic Acid In Leaves Of Annona Squamosa . Int J Pharm Pharm Sci, Vol 4, Issue 3, 144-147. 
8. H.Soni,Sarvesh Sharma,sita S Patel,K mishra A K Singhai.Preliminary phytochemical screening and HPLC analysis of flavonoids from methanolic extract of leaves of Annona Squamosa.IRJP 2(5),2011,242-246.

9. Himesh Soni, A. K. Singhai, Sarvesh Sharma, Jitender K Malik. Evaluation of Leaves of Aqueous Extract of Coleus Aromaticus and Methanolic Extract of Annona Squamosa Extracts on Cell Viability . Am. J. PharmTech Res. 2012; 2(4),935-944.

10. H Soni, G Nayak, SS Patel, K Mishra, AK Singhai, P Swarnkar, AK Pathak. Synergistic effect of polyherbal suspension of Punica granatum and Coleus aromaticus in evaluation of wound healing activity.J Herbal Med Toxicol 5 (1), 111-115

11. Nayak Shivananda, Nalabothu Poorna and Adogwa Andrew Evaluation of wound healing activity of Allamanda cathartica. L. andLaurus nobilis. L. extracts on rats. BMC Complement Altarn Med,2006;6(12):1-10.

\section{AJPTR is}

- $\quad$ Peer-reviewed

- bimonthly

- Rapid publication

Submit your manuscript at: editor@ajptr.com

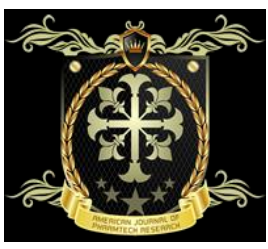

